\title{
Social Responsibility
}

\begin{abstract}
In this chapter, the authors analyze the artifacts in which students explore social responsibility. A broad understanding of social responsibility includes nonhumans and nature. In the chapter, the authors approach social responsibility through two subthemes: Social and civic competences and sustainable development. The analysis shows how students learned to address social responsibility to encounter the other and participate in the collaboration with other people. Many of them, however, took an anthropocentric view, centered on humans. The older students were able to extend the idea of social responsibility to the wellbeing of nonhumans, nature, sustainability, and the Earth.
\end{abstract}

Keyword Social responsibility - Social competence $\cdot$ Sustainable development · Participation

\section{Extending the Notion of Responsibility: I, We, Animals, Environment, and the Earth}

Responsibility is always about how "I" as an independent and egocentric person can encounter the other who is not "me." This encounter may lead to a fight, indifference, friendship, or love, but also to responsibility. Responsibility can be described as a human relationship at its highest level

(C) The Author(s) 2022

T. Lähdesmäki et al., Learning Cultural Literacy through

Creative Practices in Schools, https://doi.org/10.1007/978-3-030-89236-4_6 
of sociality, close to duty. For Levinas $(1985,95)$, moral responsibility is "the essential, primary and fundamental structure of subjectivity." This sort of responsibility is for the other: "I am responsible for the other without waiting for reciprocity" (Levinas 1985, 97). The responsibility that Levinas has in mind is also always my responsibility, not responsibility as shared, as ours. Levinas grounds this view of responsibility in an unconditional encounter with other human beings and interprets it as the origin of all human ethical obligations toward other people. Levinas has been criticized for dismissing the question of responsibility beyond humans (e.g., Derrida 2008). One way to extend responsibility toward the nonhuman is to address the relationship between humans and nonhuman animals. The first step could be to ask: Am I prepared to take responsibility for an animal? For my own animal? For an abandoned animal? Wild animals? Do even the smallest creatures have the right to live without the interference of humans? This approach to responsibility emphasizes animal rights as part of ecological ethics (Singer 1975; Horsthemke 2018). We use the word "animal" with knowledge of the fact that the dichotomy between human and animal is often used as justification for violence-not only toward nonhuman animals but toward those human beings that are deemed "animalistic" and "other" in the Euro-American context (Butler 2004, 1-4; Wolfe 2003, 6-8). In some instances, we have decided to use the concept "nonhuman animal" to remind the reader of the constructed nature of the human/animal divide.

The kind of responsibility advocated by Levinas comes close to the notions of solidarity that Rorty $(1989$, xvi) discusses when claiming that human "solidarity is not discovered, but created by increasing our sensitivity to the particular details of the pain and humiliation of others, unfamiliar sorts of people." It is easy to feel solidarity with a close friend or family members, but less easy to do so with unfamiliar sorts of people. How can I feel solidarity, for instance, with a newcomer to my school class? Or with nonhuman nature? These were some of the questions that the Cultural Literacy Learning Programme (CLLP) posed to students.

Responsibility can be approached from the point of view of "I" or "we." The latter can be defined as social responsibility, which various social agents increasingly emphasize. It is also increasingly on the agenda of corporations, often referred to as corporate social responsibility (Crowther and Aras 2008; Aras and Crowther 2009). Our societies today face challenges that can only be solved together. One of these is human impact on the Earth's natural resources. This has prompted 
some scholars to argue that humankind has recently left behind the era of the Holocene- "Recent Whole," the postglacial geological epoch of the past ten to twelve thousand years - and entered the Anthropocene, an era dominated by increasing, obviously lasting, human influence on the environment (Ehlers and Krafft 2006; cf. Visconti 2014).

Due to the pressing ecological problems caused by the Anthropocene, sustainable development is now an unavoidable part of school curricula across Europe-though its role, focus, and implementation varies greatly and it may even be marginalized. Recent scholars of educational science have taken the idea of the Anthropocene seriously and reflected on how the future of the Earth is discussed in environmental and sustainability studies (Ehlers and Krafft 2006). These studies can be perceived as "Earth literacy" seeking to find solutions to enhance the sustainable future of our planet (see Gosselin et al. 2019; for environmental literacy see Reynolds et al. 2010). While some scholars stress the aspect of environmental health and take an interdisciplinary approach (see Hursh et al. 2011), others focus on the concept of environmental justice and a sense of place (see Palmer 2006). Moreover, ecosocial and ecojustice education have extended the idea of social responsibility to include the broader nonhuman world (Salonen 2014; Martusewicz et al. 2020). In this line of thinking, human wellbeing is seen as deeply connected to the wellbeing of the natural environment, and therefore education should focus on advancing both.

In this chapter, we move from discussing responsibility between humans as outlined by Levinas to encompass broader social relations, and finally the nonhuman. As the United Nations' Human Development Report (2007) emphasizes, there is an urgent need for human solidarity to fight climate change together in a divided world. In its broadest meaning, social responsibility can thus be understood as Earth literacy that covers human responsibility for the fate of the entire biosphere. This sense of responsibility emanates from concern about unseen and anticipated future events: How can we take responsibility for the future of the planet? The challenge is that while adults teach children this kind of "planetary responsibility" (Salonen and Åhlberg 2012), they often neglect to take it. As noticed by Žižek $(2008,94)$, we know all about the threat of ecological catastrophe "but we somehow don't really believe that it can happen." Hence, the EU still sees education as key to mitigating climate change and other ecological crises. In 2020, the European Commission published the EU Biodiversity Strategy for 2030, one aim of which was to train people 
in skills to protect and restore biodiversity and the functioning of Earth's ecosystems (EC 2020). This Earth literacy connects to the cultural literacy promoted by the DIALLS project. Byrne (2016) has explored learnercentered activities to advance environmental and sustainability teaching and learning. The CLLP seeks to advance such learner-centered activities.

\section{The ClLP Approach To AND DATA ON SOCIAL RESPONSIBILITY}

In our data, we approach social responsibility through two subthemes: Social and civic competences, and sustainable development. We define social competence as including personal, interpersonal, and intercultural competences, covering all forms of behavior that equip individuals to effectively and constructively participate in social life in increasingly diverse societies and to resolve conflict where necessary. We perceive civic competence as equipping individuals to fully participate in civic life, based on knowledge of key social and political concepts and structures and a commitment to active and democratic participation (DIALLS 2018; EP \& CofEU 2006). Since the 1980s, sustainable development has become a highly influential concept in national and international policymaking for governments, organizations, and businesses alike. This has led to a plethora of definitions and interpretations of the concept (Mebratu 1998, 494). In the CLLP, we relate sustainable development to various social, societal, economic, and environmental issues and define it as meeting the needs of present generations without jeopardizing the ability of future ones to meet theirs, thus ensuring a good quality of life and a livable environment both for current and future generations (DIALLS 2018).

The cultural texts used in the lessons on social and civic competences were the book Mein weg mit Vanessa (I walk with Vanessa 2018) by Kerascoët and the films Le velo de l'elephant (The Elephant and the Bicycle 2014) by Olesya Shchukina, and Igel und die Stadt (The Hedgehogs and the City 2013) by Evalds Lacis. These texts deal with themes of participating in social life and resolving problems and conflicts, such as bullying, exclusion, and diminishing animal habitats. To explore sustainable development, we used the books Changeons! (Let's change! 2017) by Francesco Guistozzi and Free the Lines (2016) by Clayton Junior, and the film Going fishing (2018) by Guldies. These texts deal with different 
aspects of climate and environmental change, such as the transformation of coastal life, everyday decision-making, and justice and equality in globalization. To explore both subthemes, we used the book Balbuirdia (Shambles 2015) by Teresa Cortez and the film Chiripajas (2017) by Olga Poliektova and Jaume Quiles that deal with overconsumption and pollution.

Teachers provided students with discussion topics and points of view to guide their exploration of social responsibility. In their artifacts, the students portrayed social responsibility as a key for the wellbeing of humans and animals, nature, and the sustainability of the Earth. The data we use in this chapter includes 190 works from Germany (27), Israel (77), Lithuania (36), Portugal (15), Spain (16), and the UK (19). Children from the first and second age groups explored social and civic competences, while the youngest and oldest students learned about sustainable development. These subthemes were intertwined in the students' creative practice during the lessons.

Art and literature can offer imaginative solutions to contemporary phenomena and invite viewers and readers to consider other points of view, whether human or nonhuman (see Karkulehto et al. 2020; Lähdesmäki and Koistinen 2021). Writing on art and ecojustice education, Foster and Martuzewicz define imagination "as an essential means of engaging the forms of responsibility needed to generate healthy communities": Since art has potential to stimulate imagination, they call for creative practices to be included in education (Foster and Martusewicz $2019,6-7)$. Using art, such as wordless texts, in teaching social responsibility toward human beings and the biosphere is therefore justifiable.

\section{Social COMPETENCE as the Ability to InClude Others}

The book I walk with Vanessa, aimed at the youngest students, deals with social and civic competences by encouraging its readers to respond to an "unfamiliar other." In the story, Vanessa is new in class and is initially bullied or ignored by her classmates. One of the girls in the class nevertheless empathizes with Vanessa and helps her to integrate into the class. They meet other students and, finally, Vanessa starts to feel happy as she becomes a member of the group. The girl who noticed Vanessa's unhappiness can be interpreted from the Rortian and Levinasian point of view 
of responsibility and solidarity: This girl is able to feel the pain of the other, face her unconditionally, take responsibility, and act accordingly.

For this lesson, students were instructed to "draw ways in which they could make their new classmate feel part of their community." Our analysis of the artifacts and their captions indicates two tendencies in responding to the task. Some of the students seemed to avoid a personal encounter with a newcomer, depicting them as already integrated into the everyday activities of the class. One student had even changed the dynamics of the situation by imagining a group of newcomers with only one student welcoming them. Both the artifact and its caption indicate a willingness to include the newcomers, and that the student has the power to do it: "I would let them play hopscotch with me. I would let them go first on the $\mathrm{AB}$ frame [in the playground]. I would give them a flower and say 'I'm your friend'."

Some of the artifacts revealed the students' willingness to meet the other in person, to see "the face of the other" in Levinas' words (1985, 96). In one artifact, a student is meeting a girl who looks like Vanessa in the book and sharing with her the rules of a game she needs to know in order to be part of the community of her class (Fig. 6.1). In the caption, the student addresses the newcomer directly, including her in the community: "I'm showing how you do the thing like football. You could all go and play hide and seek." Another artifact depicts pairs of children in a playground, some of them holding hands (Fig. 6.1). In its caption, the student suggests friendship to a newcomer with a direct question: "I could say 'hello, do you want to be my friend'? We could go on the AB [frame in the playground] together and play on it together." In the artifact, the response to encounter with the other is to include and create togetherness: One student says to the other "Follow me" to which the other responds "OK." In the artifacts that emphasize encountering the newcomer in person, both the creator and the newcomer they imagine could be depicted with distinct characteristics: The creators recognize them as individuals with personal features (Fig. 6.1, upper drawing).

\section{The Interrelation Between Social and Civic Competences and Sustainable Development}

In the CLLP, our understanding of social responsibility is broad; it includes the environment and sustainability. I walk with Vanessa is the only cultural text used to explore social responsibility that clearly focuses 

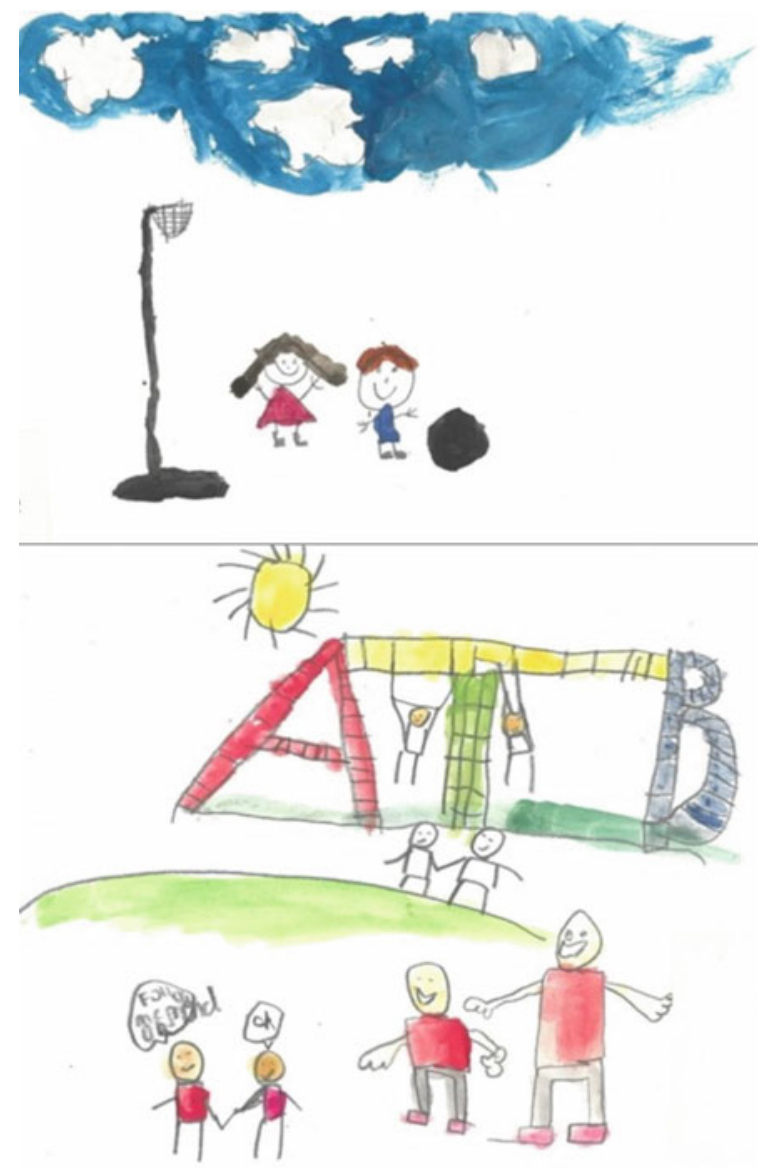

Fig. 6.1 Drawings by two students in the first age group from the UK exploring how to make a new classmate feel part of the community

on human social relations only. The other two lessons-stimulated by the films The Hedgehogs and the City and The Elephant and the Bicycle, both aimed at the students in the second age group—also deal with human responsibility for nonhuman animals and the Earth.

The story of The Hedgehogs and the City starts when the hedgehogs awake from their hibernation only to find themselves in a town 
constructed by humans, instead of the woods they went to sleep in. They have to live together with people who constantly face various troubles: Keys fall down the drain, a ball gets stuck in a tree, a child cries, and so on. Different animals in the story kindly help humans to solve these problems. An unexpected plot twist reveals that the animals have a secret project: They ask for money for their help in order to persuade the people to leave the place, bulldoze the city, and return it to the wilderness. The story emphasizes humans' selfishness and lack of responsibility for nonhumans and the environment.

In this lesson, the students were instructed to design a park for their community. Perhaps since this task was rather anthropocentric, the artifacts do not address the issue of humans taking over the living space of other animals. Therefore, the artifacts can be interpreted as presenting an anthropocentric understanding of the environment. For instance, a group of students states that "the park is for everyone" but the artifact itself illustrates humans in the center while animals have limited space around them. In some artifacts, students have drawn themselves playing in the park, as noted in a caption describing that "the people on the swings are us" feeling happy since "the animals feel good with us." While these artifacts seem to express responsibility for animals and seek harmony between humans and nonhumans in the park, they often focus on pets or treat animals as domesticated. Even wild animals are named creatures and human property, as one group of students states in their caption: "The red fox is Pabby, our fox." Even artifacts that do not depict human beings show traces of humans: Benches, swings, ladders, ropes for climbing, fences, and so on. It seems that for the students, a park (a human construction) is for humans first and only secondarily for other animals. Except for one student who drew a hedgehog sculpture on a high pedestal as a hero of the city, the students did not draw the hedgehogs from the film. Even though the statue in this one artifact honors the hedgehogs, it can be interpreted as a sign of anthropocentrism, where respect for animals is determined by human logic.

The Elephant and the Bicycle deals with the problem of rubbish, combining the subtheme of sustainable development with exploration of social and civic competences. In the narrative, an elephant cleans rubbish from the streets for living. It dreams of buying a bicycle and saves money to buy one, only to realize that the bicycle is too small for such a big animal. So the elephant loses interest in its work, the rubbish piles up, and people plead for the animal to return to work. In the end, the elephant 
does return and gives the bicycle to a small girl who it sees drawing a bicycle. Seeing the girl happily riding the bicycle around makes the elephant content as well. In the instructions for creating artifacts students were advised to "discuss rules/suggestions they can have in their class, school, family, or city about producing and throwing away rubbish and create a booklet which visually depicts these rules." The alternative task beyond the lesson was to create a 3D craft (model of a school or a town with houses, parks, streets, etc.) that shows how each person has a role to play in their community.

A class from the UK implemented the alternative task by jointly creating a 3D model of a town (Fig. 6.2). In its caption (probably cowritten with their teacher), they emphasize how the artifact was created together, "showing how different jobs contribute to a community and that we all have a joint social responsibility for taking care of our society. We all enjoyed designing and creating our scenes and working collaboratively." A bicycle at the center of the model functions as a sign that

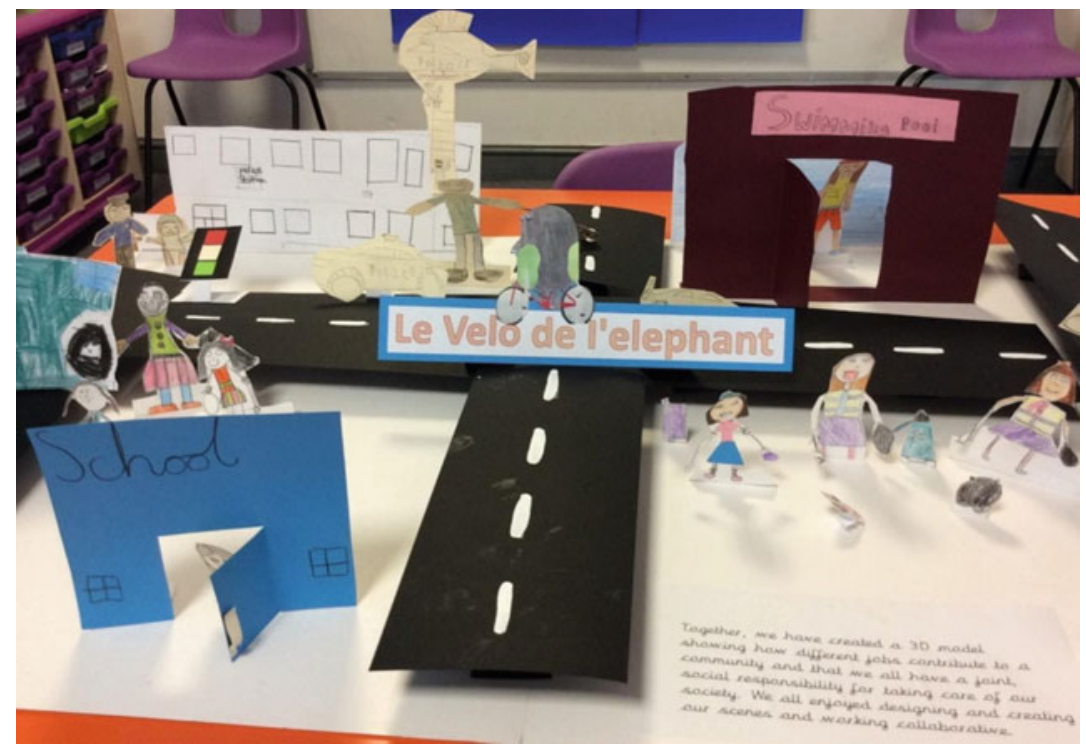

Fig. 6.2 A 3D model by a class in the second age group from the UK explores how each person has a role to play in the community 
unites the story of the film with the people and spaces in the students' living environment. In the model, some people are in a swimming pool, some are crossing the street, and some are in school. The elephant in the model has fulfilled the dream it had in the film: It is riding the bicycle. The animal is situated at the center of the model, which might suggest a less anthropocentric worldview. However, since it is anthropomorphized in the CLLP text (doing tasks usually reserved for humans and dreaming of a human means of transport), and in the model based on it, the elephant could be read as an allusion to a human doing lowpaid work. Indeed, the students' caption emphasizes that different occupations make important contributions to human society.

In the 3D models created by German students, there are no traces of the elephant. The models made from paper, plasticine, and Lego depict people doing various activities, such as happily walking their dog in a clean blossoming park, swimming in a pool, lying on the grass near a lake, playing in the yard, or working. In this task, exploration of the roles that one may have in the community was often turned into play, where the models functioned as toys. The places and environments in the models are clean: The topic of rubbish has been bypassed, pushed to the background, or "solved" by showing an ideal, clean version of the environment.

The students from a Lithuanian class created 3D models from plasticine. Their teacher suggested that they imagine which other animals could take the role of the elephant in cleaning rubbish in the film. One of the groups had titled their model "Garbage Collection" and placed it in Spain. The caption states "The Spanish beach is dirty," and continues by describing:

[A] cat carries a can to the trash. A squirrel carries pear peels. A puppy is pulling a bag with trash. A snail sweeps paper [trash]. Kaspar the Dog carries a purple packet of chips to a green trash can. A turtle transports an orange seed to a bucket. There is a lot of rubbish at sea. Animals are trying to save the beach.

The creators of a model titled "Guardians of Order" also imagined a scene where different animals are responsible for cleaning. The students write:

Our characters work in a Vilnius restaurant. We have molded three characters. They are - a dog, a crocodile [named Cocodile], and a turtle [named 
Bomb]. The turtle is getting better. The turtle collects food. Later on, it puts the food into the bag. And then the food is being carried to the container. The crocodile is collecting paper, pasta, and pieces of meat. I have molded a dog. It looks after the restaurant. It brings the garbage to the container. That's how everyone handles it.

Another group of students who titled their artifact "The Managers" also delegating the responsibility for cleanliness to animals. In their artifact, different animals are cleaning the environment. In the caption, the students note how "they [the animals] care about nature." They continue to consider their own responsibility from the perspective of the animals: "We [the animals] do not pollute nature. And you [the humans] try not to pollute nature. Take care to keep the world clean!"

The students imagined different animals cleaning rubbish since their teacher had guided them to do so. As a result, many of their artifacts do not explicitly address the core lesson of the film: Who is responsible for littering, and who has to clean up litter in a reality where people are constantly producing more and more rubbish? Is it us or the "others"? Why did humans in the film try to avoid this responsibility and why is the only responsible creature the elephant? Who does the elephant represent? Some students considered that cleaning up was the job of volunteers. As one group of Lithuanian students noticed in their caption: "The voluntary workers can collect sweepings. It will help everyone." Artifacts like this suggest that social responsibility for a shared environment can be transmitted to someone else, someone "other."

The groups of students who followed the task more closely concluded that they had responsibility and identified with the elephant, as highlighted by expressions such as "we, the students." One group of Lithuanian students created an artifact titled "Clean Forest," expressing frustration with the littering of forests and deforestation. The teacher of this group reported that the students were concerned that litter might harm animals and wanted to give a good example to others by keeping their environment clean.

In several other artifacts, the students emphasized everyone's responsibility for the environment, including their own role as "we" in cleaning up litter. In some of the captions, they discussed environmental impact in more detail, noting how sunshine may heat pieces of broken glass in the forests and cause forest fires, or how it helps nature to use reusable dishes and going to school on foot or by bike. 
Social and civic competences, including commitment to sustainable development, were explicitly referenced in some of the children's artifacts. In the lessons, social responsibility was understood in a broad sense as covering humans and nonhumans in both urban and natural settings. For Smith $(2011,20)$, ecological ethics awakens us to the wider morethan-human world through "raising questions concerning the singular significance of beings other than animals, too: Trees, fungi, rivers, rocks." Social, civic, and sustainable development competences can thus be seen as belonging to the sphere of ecological ethics.

\section{Exploring Sustainable Development}

Most of the wordless books and films used for stimulating discussion on social responsibility in the CLLP deal with topics related to sustainable development. One of these cultural texts, the book Shambles used in a lesson for the youngest age group, narrates the story of a boy who lives in a very messy bedroom cluttered with toys. The mess starts to grow, taking on a life of its own and scaring the boy. The story helps the students to discuss overconsumption and the need for a sustainable lifestyle. The children were instructed to make artifacts in which they turn their "want pile" into a "mess monster." They created installations by making piles of items such as toys they had brought from home. The aim of the lesson was to stimulate discussion about the quantity of the items that people own and purchase, and whether these are all necessary.

The film Chiripajas, also used for the youngest age group, tells the story of a little turtle who gets trapped in the rubbish left on the beach while trying to reach the ocean and unite with its family. The turtle is finally able to escape when two human hands appear in the picture to collect the trash and make way for the turtle to get to the ocean. The film includes a double message: Humans can both damage and save the environment. Students were instructed to draw a poster illustrating the impact of rubbish on animals in their local environment, to persuade someone not to litter.

The artifacts students made in this lesson reflect a deeper view on the wellbeing of animals and the environment, and thus reveal an understanding that can be described as planetary responsibility or Earth literacy. The students focus on issues such as animal rights and plastic in oceans. In their artifacts the turtle gets stuck in rubbish not only on the beach but also in the ocean. One caption states that: "I have drawn a turtle, 
it is stuck in rubbish in the Great Pacific garbage patch. It is telling people to stop using plastic, and stop throwing plastic in the sea." In their work, the students represented the plight of other sea animals and plants, attempting to save them from rubbish by persuading people to put their rubbish in bins. The artifact illustrated in Fig. 6.3 is one example of this: In it, nature (not tarnished by rubbish) and rubbish are clearly distinguished with colors. In the caption, the student suggests that people should put their rubbish in the bin, and repair broken items to avoid creating rubbish in the first place: "Put the things that you don't want, put them in the bin, but if it's a toy that is broken then you could fix it, fix it, fix it, fiiiiiiix it! Make it colourful."

Several of the oldest students depicted the symbol of human hands saving the Earth from pollution in artifacts created in the lesson based on the film Going Fishing. One group of these students drew the Earth lying in human hands three times (Fig. 6.4). Their artifact seems to suggest that humans need to hold the planet gently, that is, to take care of it.

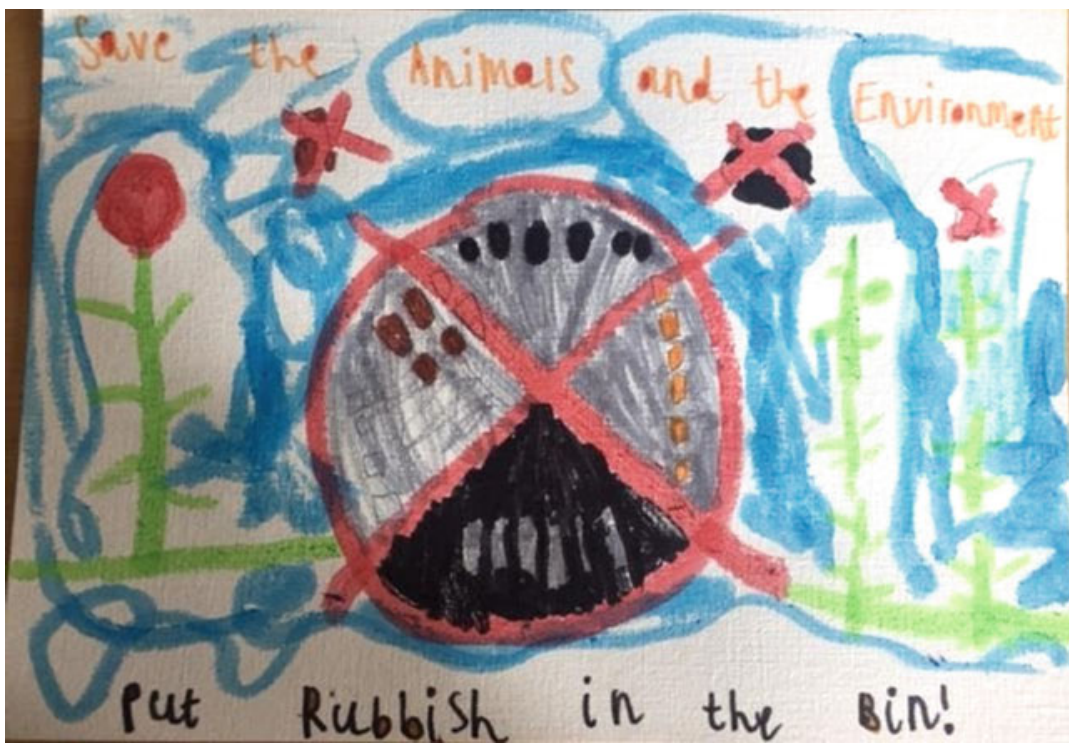

Fig. 6.3 A drawing by a student in the youngest age group from the UK exploring the impact of rubbish on animals and the environment 


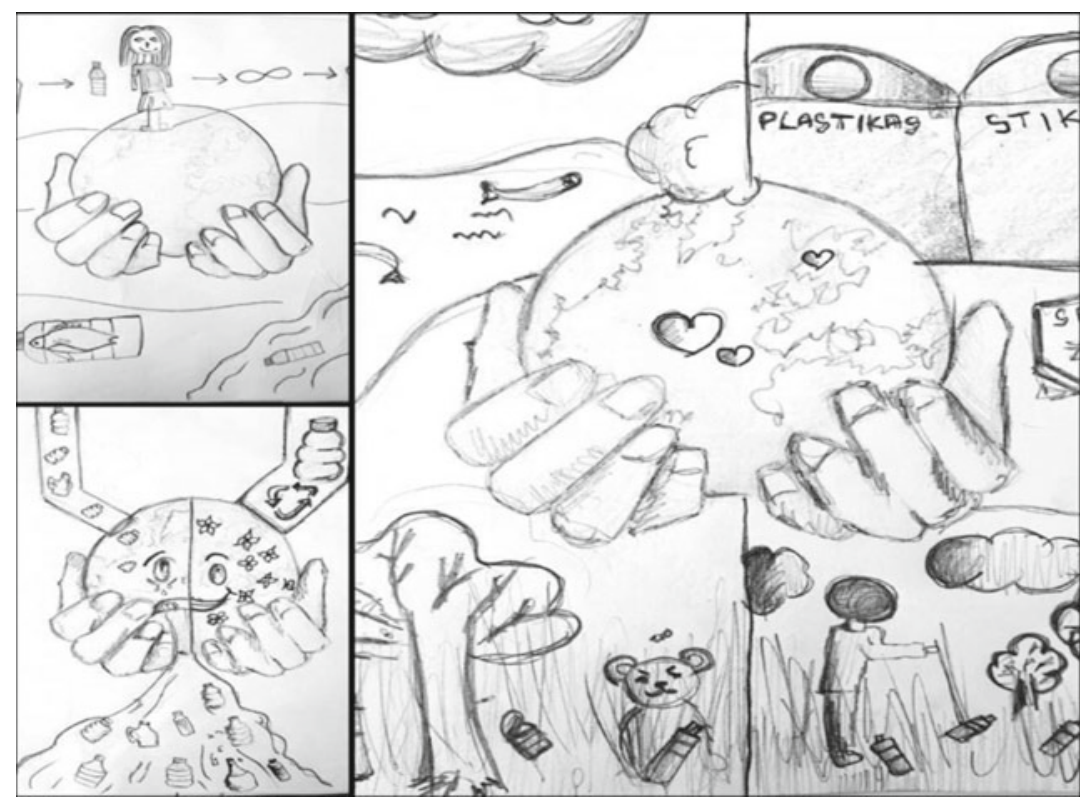

Fig. 6.4 A drawing by students in the oldest age group from Lithuania depicting the journey of a plastic bottle, exploring solutions to this nonsustainable situation

The students note in the caption how the destiny of the globe depends on human beings. However, other artifacts created in this lesson reflect more pessimistic views that humans cannot change the fate of the Earth. One group of students note in their caption that "we live immersed in consumerism, more and more products are disposable and no matter how many recycling campaigns there are, we are still generating too much waste that harms the planet and endangers future generations."

The artifacts responding to the book Let's change! include more optimistic views of the future of the Earth. In this lesson, the oldest students were instructed to select one ecological problem and draw a proposed solution to highlight how the sustainability of the Earth's natural resources is everyone's responsibility. In their artifacts, the students identified various unsustainable practices and suggested ideas and tools to transform these into sustainable development, such as replacing airplanes with electric cars, or cars with using trains and bicycles, or, since many 
detached small houses leave no space for forests, building apartment blocks could leave more space for them. A teacher of a Spanish class summed up the students' optimistic discussion about the future of the Earth in his lesson diary as follows:

Plastic is abundant nowadays. We should find some solution to avoid it, such as banning plastic bags in supermarkets. If we continue to pollute and deforest our planet, we will soon have trouble living in a healthy and sustainable way. We need courageous government action to eradicate these situations and the conscious involvement of each of us in issues such as recycling, renewable energy consumption, and the conscious consumption of what we eat and buy. As we have understood from the end of the book, all is not lost. Even in the most difficult situations, it is possible for tender plants to sprout. If we all become aware of the serious situation, if we all act bravely, we can achieve great things and, above all, bring our blue planet back to life.

In sum, our analysis indicates that many of the students in all age groups understood social responsibility as "our" responsibility to encounter the "other" ethically. In their creative works, however, students often approached social responsibility from an anthropocentric point of view. This is at least partly due to the instructions and suggestions given in the CLLP. Nevertheless, the wordless picture books and films with their nuanced stories about human and nonhuman relations encouraged the students to extend the idea of social responsibility to include the planet, paying attention to nonhumans, nature, and sustainability in general. Our analysis thus supports the claims that art can be a fruitful framework for teaching students to consider the viewpoints of others and to contemplate complex ecological issues.

\section{REFERENCES}

Aras, G., and D. Crowther. 2009. "Corporate Sustainability Reporting: A Study in Disingenuity?" Journal of Business Ethics 87: 279-288.

Butler, J. 2004. Undoing Gender. New York: Routledge.

Byrne, L. B., ed. 2016. Learner-Centered Teaching Activities for Environmental and Sustainability Studies. Cham: Springer.

Crowther, D., and G. Aras. 2008. Corporate Social Responsibility. London: Bookboon. 
Derrida, J. 2008. The Animal that therefore I Am [Animal que donc je suis], edited by M.-L. Mallet, translated by D. Wills. New York: Fordham University Press.

DIALLS. 2018. “Cultural Analysis Framework.” https://dialls2020.eu/wp-con tent/uploads/2019/09/resubmitted-cultural-analysis-framework-with-covers heet-.pdf.

EC (The European Commission). 2020. "Communication from the Commission to the European Parliament, the Council, the European Economic and Social Committee and the Committee of the Regions. EU Biodiversity Strategy for 2030. Bringing nature back into our lives." $\operatorname{COM}(2020) 380$ final, 20 May. Brussels: European Commission. https://eur-lex.europa.eu/legal-con tent/EN/TXT/?uri=CELEX:52020DC0380.

Ehlers, E., and T. Krafft, eds. 2006. Earth System Science in the Anthropocene. Emerging Issues and Problems. Cham: Springer.

EP \& CofEU (The European Parliament and the Council of the European Union). 2006. "Recommendation of the European Parliament and of the Council of 18 December 2006 on Key Competences for Lifelong Learning. (2006/962/EC)." Official Journal of the European Union L 394: 10-18.

Foster, R., and R. A. Martusewicz. 2019. "Introduction: Contemporary Art as Critical, Revitalizing, and Imaginative Practice toward Sustainable Communities." In Art, EcoJustice, and Education: Intersecting Theories and Practices, edited by R. Foster, J. Mäkelä, and R. A. Martusewicz, 1-9. New York: Routledge.

Gosselin, D. C., A. E. Egger, and J. J. Taber. 2019. Interdisciplinary Teaching About Earth and the Environment for a Sustainable Future. Cham: Springer.

Horsthemke, K. 2018. Animal Rights Education. Cham: Springer.

Hursh, D. W., C. A. Martina, H. B. Davis, and M. A. Trush. 2011. Teaching Environmental Health to Children. An Interdisciplinary Approach. Cham: SpringerBriefs in Environmental Science.

Karkulehto, S., A.-K. Koistinen, and E. Varis, eds. 2020. Reconfiguring Human, Nonbuman and Posthuman in Literature and Culture. New York: Routledge. Levinas, E. 1985. Ethics and Infinity. Pittsburgh: Duquesne University Press.

Lähdesmäki, T. and A.-K. Koistinen. 2021. "Explorations of Linkages Between Intercultural Dialogue, Art, and Empathy." In Dialogue for Intercultural Understanding: Placing Cultural Literacy at the Heart of Learning, edited by F. Maine and M. Vrikki. Cham: Springer.

Martusewicz, R. A., J. Edmundson, and J. Lupinacci. 2020. "Introduction: The Purposes of Education in an Age of Ecological Crises and Worldwide Insecurities." In Ecojustice Education: Toward Diverse, Democratic, and Sustainable Communities, edited by R. A. Martusewicz, J. Edmundson, and J. Lupinacci, 1-20. New York: Routledge. 
Mebratu, D. 1998. "Sustainability and Sustainable Development: Historical and Conceptual Review.” Environmental Impact Assessment Review 18 (6): 493520.

Palmer, C., ed. 2006. Teaching Environmental Ethics. Leiden: Brill.

Reynolds, H. L., E. S. Brondizio, and J. M. Robinson. 2010. Teaching Environmental Literacy. Across Campus and Across the Curriculum. Bloomington: Indiana University Press.

Rorty, R. 1989. Contingency, Irony, and Solidarity. Cambridge: Cambridge University Press.

Salonen, A. 2014. "An Ecosocial Approach in Education." In Schooling for Sustainable Development in Europe: Concepts, Policies and Educational Experiences at the End of the UN Decade of Education for Sustainable Development, edited by R. Jucker and R. Mathar, 231-233. Berlin-Heidelberg: Springer.

Salonen, A. O., and M. K. Åhlberg. 2012. "The Path Towards Planetary Responsibility-Expanding the Domain of Human Responsibility Is a Fundamental Goal for Lifelong Learning in a High-Consumption Society." Journal of Sustainable Development 5 (8): 13-26.

Singer, P. 1975. Animal Liberation: A New Ethics for our Treatment of Animals. New York: Random House.

Smith, M. 2011. Against Ecological Sovereignty. Ethics, Biopolitics, and Saving the Natural World. Minneapolis: University of Minnesota Press.

UN (United Nations). 2007. Human Development Report 2007/2008. Fighting Climate Change: Human Solidarity in a Divided World. New York: Palgrave Macmillan.

Visconti, G. 2014. “Anthropocene: Another Academic Invention?” Rend. Fis. Acc. Lincei 25: 381-392. https://doi.org/10.1007/s12210-014-0317-x7-x.

Wolfe, C. 2003. Animal Rites: American Culture, the Discourse of Species, and Posthumanist Theory. Chicago: University of Chicago Press.

Žižek, S. 2008. Violence: Six Sideways Reflections. New York: Picador. 
Open Access This chapter is licensed under the terms of the Creative Commons Attribution 4.0 International License (http://creativecommons.org/licenses/ by $/ 4.0 /$ ), which permits use, sharing, adaptation, distribution and reproduction in any medium or format, as long as you give appropriate credit to the original author(s) and the source, provide a link to the Creative Commons license and indicate if changes were made.

The images or other third party material in this chapter are included in the chapter's Creative Commons license, unless indicated otherwise in a credit line to the material. If material is not included in the chapter's Creative Commons license and your intended use is not permitted by statutory regulation or exceeds the permitted use, you will need to obtain permission directly from the copyright holder.

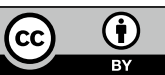

